\title{
SECOND RECORD OF Tityus bahiensis (SCORPIONES, BUTHIDAE) FROM
}

\section{VENEZUELA: EPIDEMIOLOGICAL IMPLICATIONS}

\author{
DE SOUSA L. (1), BORGES A. (2), MANZANILLA J. (3, 4), BIONDI I. (5),
}

AVELLANEDA E. (1)

(1) Center of Health Sciences Investigations, Anzoátegui Institute of Investigations and Development (INDESA), School of Medicine, University of Oriente, Puerto La Cruz, Anzoátegui, Venezuela; (2) Laboratory of Animal Toxins, Center for Biosciences and Molecular Medicine, Institute for Advanced Studies (IDEA), Institute of Experimental Medicine, Faculty of Medicine, Central University of Venezuela, Caracas, Venezuela; (3) Museum of the Agricultural Zoology Institute (MIZA), Institute of Agricultural Zoology, Faculty of Agronomy, Central University of Venezuela, Aragua, Venezuela; (4) Museum of Natural Sciences, Madrid, Spain; (5) Laboratory of Venomous Animals and Herpetology, Department of Biological Sciences, State University of Feira de Santana, Feira de Santana, Bahia State, Brazil.

ABSTRACT: This work reports the second record of the scorpion Tityus bahiensis Perty from Venezuela. The specimen was found alive in a wardrobe at a hotel resort in Margarita Island, northeastern Venezuela. Morphological characterization allowed its assignment to the Tityus bahiensis population inhabiting the southernmost area of the species' geographic range, e.g. the state of São Paulo in Brazil, northern Argentina and Paraguay. The fact that the only available Venezuelan antiscorpion (anti-Tityus discrepans) serum does not neutralize the effects of alpha- and betatoxin from Tityus serrulatus venom (which resembles in composition that of $T$. bahiensis) constitutes a warning to local clinicians confronted with envenomations by noxious species transported to Venezuela from Brazil by human agency.

KEY WORDS: Tityus, Scorpiones, Buthidae, exotic species.

CONFLICTS OF INTEREST: There is no conflict.

\section{CORRESPONDENCE TO:}

LEONARDO DE SOUSA, Centro de Investigaciones en Ciencias de la Salud (CICS), Instituto de Investigación y Desarrollo Anzoátegui (INDESA) y Escuela de Medicina, Universidad de Oriente, Núcleo de Anzoátegui, Puerto La Cruz 6023, P. O. Box 4774, Anzoátegui, Venezuela. Email: leonardodesousa@yahoo.com. 


\section{INTRODUCTION}

The introduction of noxious animals into geographical areas where they are not prevalent can have epidemiological implications depending on whether the species becomes established in the new area. The scientific literature contains numerous examples of arachnids $(11,29)$, including scorpions $(11,27,28)$, reptiles $(13,20)$ and other venomous animals $(5,12)$, that have been carried by anthropochorous dispersal for distances over hundreds of kilometers (21). For instance, Tityus serrulatus Lutz and Mello, the most toxic Brazilian scorpion species, has been transported to areas as distant as Mato Grosso and the Federal District from its original locality in the savannas of the state of Minas Gerais, southeastern Brazil (1618, 30). More recently, T. serrulatus has been found in the city of Corrientes, in northern Argentina (6). In Venezuela, populations of Centruroides gracilis Latreille, a scorpion endemic to the Antilles, can be found in the main ports since the nineteenth century $(8,9)$.

Rodríguez-Acosta and Reyes-Lugo (25) published the finding of a dead female specimen of the Brazilian scorpion Tityus bahiensis Perty at an apartment building in eastern Caracas, the capital city of Venezuela. We wish to report the second record of this species from the country. The specimen was found alive at a hotel resort in Margarita Island, Nueva Esparta State, northeastern Venezuela, about 350km east of Caracas.

Taxonomic assignment of the specimen was performed according to Lourenço (15). Measured morphological characters are presented in milimeters $(\mathrm{mm})$ and were taken under an Olympus ${ }^{\circledR}$ Zoom Stereo Microscope System (10x) using a digital caliper (Mitutoyo ${ }^{\circledR}$ ). The specimen has been deposited as voucher in the Collection of Scorpions of the Laboratory of Toxinology, Center of Health Sciences Investigations, School of Medicine, University of Oriente [Colección de Escorpiones del Laboratorio de Toxinología-CELT, Centro de Investigaciones en Ciencias de la Salud-CICS, Escuela de Medicine, Universidad de Oriente - UDO], Anzoátegui Campus, Venezuela.

The specimen found in Margarita Island is an adult male Tityus bahiensis, recorded with the catalogue number CELT-1069 (Figure 1). Identification was kindly confirmed by Dr. Mario de Maria, Department of Biology, Institute of Biological Sciences, Federal University of Minas Gerais [Departamento de Biología, Instituto de Ciencias Biológicas, Universidade Federal de Minas Gerais], Belo Horizonte, Minas Gerais 
State, Brazil. The scorpion was found alive on March 28, 2005 by M. I. Velásquez inside a wardrobe at a hotel resort in Porlamar City, southern Margarita Island, Nueva Esparta State (the name of the resort and photographic evidence of the finding are kept as vouchers at the CICS). The specimen was sprayed with insecticide and kept in isopropilic alcohol. Ten days later it was sent to the Toxinology Laboratory, CICS, for identification, where it was washed with doubledistilled water, fixed with Dietrich solution (8) and later preserved in $70 \%(\mathrm{v} / \mathrm{v})$ ethanol and entered into the CELT collection.

\section{Taxonomy}

Color: body deep brown, legs reddish yellow, pedipalps reddish brown. Pedipalps and legs bear dark spots. Metasome: segments I to III reddish brown; segments IV and $\mathrm{V}$ blackish brown (darker than the preceding segments). Metasome with 10-108-8-5 keels. Pedipalp tibia with serrated margins. Pedipalp fingers with 17 oblique rows of granules. Subaculear tubercle strong and spinoid. Number of pectineal teeth (right/left): 23/23. Measurements (in $\mathrm{mm}$ ): carapace length 8.06, carapace width 8.51, length of right hand 14.81 , width of right hand 4.69 , length of movable finger 9.25 , length of right tibia 7.89 , length of right femur 7.55 , length of mesosoma 20.79 , caudal segments: I (width/length) 4.79/5.25; II 4.83/6.58; III 4.97/7.33; IV 5.00/8.57; V 5.14/9.78; telson length 8.24; length of right pecten 5.96; total length 74.6.

\section{Comments}

The morphological characteristics of the specimen hereby described resemble those of the meridional $T$. bahiensis populations. Lourenço (15) refers that $T$. bahiensis Perty is a polymorphic species with serrated margins on the pedipalp tibia, and fingers with 17 oblique rows of granules; between 18 and 23 pectineal teeth; metasoma with 10-10-8-8-5 keels and a strong, spinoid subaculear tubercle. Tityus bahiensis populations include individuals of medium to large size (55-68mm). Lourenço (14) reported that $T$. bahiensis specimens exhibit various pigmentation patterns depending on their geographic origin within Brazil. Accordingly, individuals from the southernmost areas of the species' geographic range (e.g. São Paulo State, northern Argentina and Paraguay) bear more conspicuous and darker spots than those found on specimens from the northern areas (states of Goiás and Minas Gerais, Brazil), which consistently have smaller spots. The specimen hereby reported 
represents the second record of the species from Venezuela. The first record was published by Rodríguez-Acosta and Reyes-Lugo (25) based on an individual found dead in a shoe box at an apartment building in eastern Caracas. The authors discussed on the importance of taking appropriate security measures at ports and airports to minimize the risks associated with the introduction of exotic venomous species. In addition, Rodríguez-Acosta and Reyes-Lugo (25) hypothesized on the potential health problem that could be created in Venezuela and other regions where T. bahiensis is not endemic, if the species were to become established.

Venezuela possesses a high arachnid biodiversity highlighted by the presence of 184 scorpion species described up to 2006 (26). The genus Tityus, of significant medical importance in Venezuela $(2,3,7)$, contains 52 taxa thus far described, mostly distributed in the densely-populated north-central, eastern and western mountainous ranges of the country $(3,7)$. Inasmuch as the population inhabiting this section of the Venezuelan territory has been estimated as 9,703,479 (approximately 45\% of the country's population; 1995 estimates) (7), Tityus scorpion envenomation can be rated as endemic and as a health hazard, the magnitude of which depends on the geographic region involved $(2,3,7)$. For Margarita Island, in the Nueva Esparta State, only two scorpion species have been reported, i.e. Rhopalurus laticauda Thorell $(9,19)$ and Tityus neoespartanus González-Sponga (10). The finding of this $T$. bahiensis specimen can be related to the high affluence of tourists to the island from Brazil and Argentina, particularly during winter months.

The order Scorpiones contains species with various degrees of ecological plasticity. Fortunately, $T$. bahiensis is not a parthenogenetic species like $T$. serrulatus Lutz and Mello, the most toxic of all Brazilian scorpions $(17,22)$. An opportunistic species, $T$. serrulatus has recently invaded new areas in southeastern Brazil, as a direct consequence of human activities, displacing less noxious species such as $T$. fasciolatus (endemic to the Federal District) from their habitat $(16-18,30)$.

Globalization of the world economy has certainly increased the opportunity for dispersal of many species as a result of touristic and commercial activities $(23,24$, 31). Additionally, infrastructure megaprojects destabilize natural ecosystems and increase the chance for invasion by opportunistic species, which are prolific, highly vagile and competitive, such as the parthenogenetic $T$. serrulatus (18). Some exotic species can subsist for years or decades at low population densities until they turn into destructive species as a result of a sudden increase in growth rate (23). 
As far as the risk associated with the introduction of foreign species is concerned, Ojasti (23) has referred that two main areas are under impact: agricultural activities and the environment. We wish to add a third category: the area associated with clinical and epidemiological risks, both human and veterinary. In this sense, Borges et al. (4) have found that antibodies anti-Tityus discrepans (the prevalent scorpion species in north-central Venezuela) do not abolish the effect of $T$. serrulatus alphaand beta-toxins, the most lethal neurotoxins produced by this Brazilian species. It has been shown that $T$. bahiensis produces neurotoxins highly similar to those found in $T$. serrulatus venom (1), which also cross-react with anti-T. serrulatus antivenom (22). Inasmuch as the only available antiscorpion antivenom in Venezuela is produced against $T$. discrepans, there is the possibility that envenomation by foreign Tityus in Margarita Island (or elsewhere in mainland Venezuelan where tourism is a main activity) could not be treated adequately. Although the restricted ecological plasticity of $T$. bahiensis makes it improbable that a population could be established in Venezuela, local doctors as well as Venezuelan health authorities should be warned of the possibility that envenomation by this species may take place in or near tourist resorts. Also, adequate custom measures should be taken to avoid the introduction of the parthenogenetic scorpion, Tityus serrulatus into Venezuela.

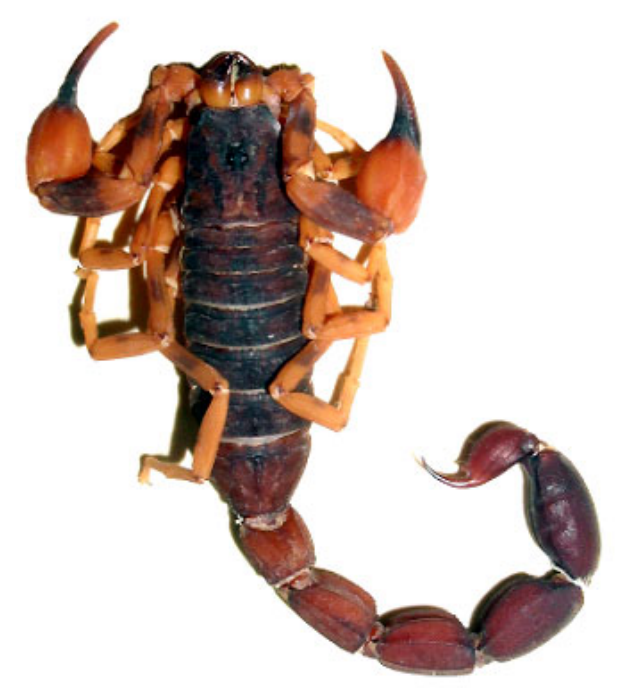

Figure 1. Male specimen of Tityus bahiensis Perty (CELT-1069) collected alive in Margarita Island, northeastern Venezuela. Scale $=1 \mathrm{~cm}$. 


\section{ACKNOWLEDGMENTS}

We wish to express our thanks to Professor Dr. Mario De Maria, Institute of Biological Sciences, Federal University of Minas Gerais [Instituto de Ciencias Biológicas, Universidade Federal de Minas Gerais - UFMG], Belo Horizonte, Minas Gerais State, Brazil, for kindly confirming the identification of the $T$. bahiensis specimen reported in this work.

\section{REFERENCES}

1 BECERRIL B., MARANGONI S., POSSANI L. Toxins and genes isolated from scorpions of the genus Tityus. Toxicon, 1997, 35, 821-35.

2 BORGES A. Escorpionismo en Venezuela. Acta Biol. Venez., 1996, 16, 65-75.

3 BORGES A., DE SOUSA L. Escorpionismo en Venezuela: una aproximación molecular, inmunológica y epidemiológica para su estudio. Rev. Fac. Farm. Caracas, 2006, 69, 15-27.

4 BORGES A., TSUSHIMA RG., BACKX PH. Antibodies against Tityus discrepans venom do not abolish the effect of Tityus serrultus venom on the rat sodium and potassium channels. Toxicon, 1999, 37, 867-81.

5 BRISSET IB., SCHAPPER A., POMMIER P., HARO L. Envenomation by Amazonian freshwater stingray Potamotrygon motoro: two cases reported in Europe. Toxicon, 2006, 47, 32-4.

6 CAMARGO FJ., RICCIARDI A. Sobre la presencia de un escorpión Tityus serrulatus Lutz e Mello (Scorpiones, Buthidae) en la ciudad de Corrientes. In: COMUNICACIONES CIENTÍFICAS Y TECNOLÓGICAS, Corrientes, 2000. Actas... Corrientes: Universidad Nacional del Nordeste, 2000. 3p.

7 DE SOUSA L., PARRILLA-ÁLVAREZ P., QUIROGA M. An epidemiological review of scorpion stings in Venezuela: the northeastern region. J. Venom. Anim. Toxins, 2000, 6, 127-65.

8 GONZÁLEZ-SPONGA MA. Escorpiones de Venezuela. Caracas: Cuadernos Lagoven, 1984. 125p.

9 GONZÁLEZ-SPONGA MA. Guía para identificar escorpiones de Venezuela. Caracas: Cuadernos Lagoven, 1996. 204p. 
10 GONZÁLEZ-SPONGA MA. Arácnidos de Venezuela: Seis nuevas especies del género Tityus y redescripción de Tityus pococki Hirts, 1907, Tityus rugosus (Schenkel, 1932) n. comb. y Tityus nematochirus Mello-Leitão, 1940 (Scorpionida: Buthidae). Acta Biol. Venez., 1996, 16, 1-38.

11 HARO L., POMMIER P. Envenomation: a real risk of keeping exotic house pets. Vet. Hum. Toxicol. , 2003, 45, 214-6.

12 LITOVITZ TL., KLEIN-SCHWARTZ W., DYER KS., SHANNON M., LEE S., POWERS M. 1997 Annual report of the American Association of Poison Control Centers Toxic Exposure Surveillance System. Am. J. Emerg. Med., 1998, 16, 443-97. 13 LONATI D., BUTERA R., CIMA M., COZZIO S., LOCATELLI C., MANZO L. Exotic snakes in Europe. A case of Mexican Moccasin (Agkistrodon bilineatus) snakebite. Presse Med., 2004, 33, 1582-4.

14 LOURENÇO WR. La véritable identité de Tityus bahiensis (Perty, 1834). Description de Tityus eickestedtae n. sp. (Scorpiones, Buthidae). Rev. Arachnol., 1982, 4, 93-105.

15 LOURENÇO WR. Scorpions of Brazil. Paris: Editions de L'If, 2002. 308p.

16 LOURENÇO WR., CLOUDSLEY-THOMPSON JL. Effects of human activities on the environment and on the distribution of dangerous species of scorpions. In: BON C., GOYFFON M. Eds. Envenomings and their treatments. Lyon: Foundation Marcel Mérieux, 1996. p.49-60.

17 LOURENÇO WR., CLOUDSLEY-THOMPSON JL., CUÉLLAR O., VON EICKSTEDT VRD., BARRAVIERA B., KNOX MB. The evolution of scorpionism in Brazil in recent years. J. Venom. Anim. Toxins, 1996, 2, 121-34.

18 LOURENÇO WR., CUÉLLAR O. Scorpions, scorpionism, life history strategies and parthogenesis. J. Venom. Anim. Toxins, 1995, 2, 51-62.

19 MANZANILLA J, DE SOUSA L. Ecología y distribución de Rhopalurus laticauda Thorell, 1876 (Scorpiones: Buthidae) en Venezuela. Saber, 2003, 15, 3-14.

20 MÉRENS A., PETITJEANS F., GIDENNE S., DEBIEN B., DE RUDNICKI S., MONTAN E., HERVÉ V., SAMSON T., FOISSAUD V. Severe hypofibrinegenemia after rattlesnake envenomation in France. Ann. Biol. Clin., 2005, 63, 220-4.

21 MOTTA PC. Primeiro registro de Bothriurus asper Pocock (Scorpiones, Bothriuridae) no Distrito Federal, Brasil. Rev. Bras. Zool., 2006, 23, 300-1. 
22 NISHIKAWA AK., CARICATI CP., LIMA ML., SANTOS MC., KIPNIS TL., VON EICKSTEDT VRD., KNYSAK I., SILVA MH., HIGASHI HG., DÍAS DA SILVA W. Antigenic cross-reactivity among the venoms from several species of Brazilian scorpions. Toxicon, 1994, 32, 989-98.

23 OJASTI J. Especies exóticas invasoras. Estrategia regional de biodiversidad para los países del trópico andino. Caracas: Convenio CAN-BID, 2001. 63p.

24 RODRÍGUEZ JP. La amenaza de las especies exóticas para la conservación de la biodiversidad suramericana. Interciencia, 2001, 26, 479-89.

25 RODRÍGUEZ-ACOSTA A., REYES-LUGO M. Hallazgo de Tityus bahiensis (Perty, 1834) (Scorpiones: Buthidae) en Venezuela. Entomotropica, 2004, 19, 107-8.

26 ROJAS-RUNJAIC FJ., DE SOUSA L. Catálogo de los escorpiones de Venezuela (Arachnida: Scorpiones). Bol. Soc. Entomol. Aragonesa, 2007, 40, 281-307.

27 RUSSEL FE., MADON MB. Introduction of the scorpion Centruroides exilicauda into California and its public health significance. Toxicon, 1984, 22, 658-64.

28 TRESTAIL JH. Scorpion envenomation in Michigan: three cases of toxic encounters with poisonous stow-aways. Vet. Hum. Toxicol., 1981, 23, 8-11.

29 TAKAOKA M., NAKAJIMA S., SAKAE H., NAKAMURA T., TOHMA Y., SHIONO S., TABUSE H. Tarantula bite: two case reports of finger bite from Haplopelma lividum. Chudoku Kenkyu, 2001, 14, 247-50.

30 VON EISCKSTEDT VRD., RIBEIRO LA., CANDIDO DM., ALBUQUERQUE MJ., JORGE MT. Evolution of scorpionism by Tityus bahiensis (Perty) and Tityus serrulatus Lutz and Mello and geographical distribution of the two species in the state of São Paulo, Brazil. J. Venom. Anim. Toxins, 1996, 2, 95-105.

31 WILLIAMSON M. Invasion. Ecogeography, 1999, 22, 5-12. 